\title{
PENGARUH LIABILITAS TERHADAP PENGHASILAN BERSIH PADA BADAN PENYELENGGARAAN JAMINAN SOSIAL (BPJS) KETENAGAKERJAAN 2013-2017
}

\author{
Bisma Indrawan dan Widiani Triaelsa Agustien \\ Politeknik Piksi Ganesha Bandung \\ bismaindra1@yahoo.com, wtriaelsa@gmail.com
}

\begin{abstract}
Abstrak
Penelitian ini bertujuan untuk menganalisis pengaruh Liabilitas terhadap Penghasilan Bersih pada Badan Penyelenggaraan Jaminan Sosial (BPJS) Ketenagakerjaan periode 2013-2017. Metode penelitian yang digunakan adalah metode penelitian kuantitatif, dengan teknik pengumpulan data yang meliputi studi pustaka, studi lapangan, serta dilengkapi dengan kajian pustaka yang memiliki relevansi yang erat dengan pokok permasalahan, sedangkan analisis data menggunakan koefisien pearson product moment, koefisien determinasi, dan analisis regresi linear sederhana. Dari penelitian yang dilakukan, diperoleh data pengaruh liabilitas dengan penghasilan Bersih dan setelah diukur korelasinya adalah sebesar 0,928 yang artinya sangat kuat. Berdasarkan analisis data, terbentuk model taksiran regresi Y = 599195049263,286 + 0,130X yaitu setiap liabilitas ditingkatkan maka akan diikuti oleh peningkatan penghasilan Bersih sebesar Rp 130,- pada konstanta 599195049263,286. Serta besarnya hubungan liabilitas terhadap penghasilan Bersih berdasarkan hasil koefisien determinasi adalah sebesar 86,20\% yang artinya 13,80\% dipengaruhi oleh faktor lain. Hambatan yang dihadapi oleh perusahaan adalah: 1) adanya kenaikan beban pajak; 2) adanya beban akrual yang tinggi dan menyebabkan bertambahnya nilai liabilitas. Adapun saran yang diberikan adalah: 1) memperhatikan beban-beban yang dapat memicu bertambahnya nilai liabilitas; 2) mengadakan kembali pemulihan nilai wajar aset investasi yang tersedia dijual.
\end{abstract}

Kata kunci: Liabilitas, Penghasilan Bersih

\begin{abstract}
The purpose of this research is to analyze the influence of liability on net income at Badan Penyelenggaraan Jaminan Sosial (BPJS) Ketenagakerjaan period of 2013-2017. The method for this research used quantitative method, collected data by literature study, field study, and review of literature that relevance to the subject. While for data analysis using coefficient pearson product moment, coefficient of determination and linear regression analysis. The conducted of research, the influence of liabilities with net income and after measured correlation is 0,928 which mean very strong. Based on data analysis, a regression estimation model is formed $Y=599195049263,286+0,130 X$ that every liability increasingly, it will be followed by increase in net income by $R p$ 130,- at a constant 599195049263,286. The amount of liability relationship to net income based on the coefficient of determination is $86,20 \%$ which means $13,80 \%$ influenced by other factor. The company have to solve: 1) increase in tax payable; 2) the amount of accrual expenses that causes an increase in the value of liabilities. The advice given in this study are: 1) pay attention to expense that can trigger the increase in the value of liabilities; 2) re-establish the fair value of available investment assets.

Keywords: Liabilities, Net Income
\end{abstract}

\section{A. PENDAHULUAN}

\section{Latar Belakang Penelitian}

Indonesia merupakan negara yang bertujuan untuk memenuhi kesejahteraan dan kemakmuran rakyatnya. Hal tersebut dapat dilihat dari cita-cita yang terkandung dalam UUD 1945 dan Pembukaan Undang-Undang alenia ke-4. Untuk memenuhi kesejahteraan dan kemakmuran itu sendiri, maka negara tidak hanya berdiam diri dan mengawasi saja, namun ada usaha yang harus dilakukan.

Maka dari itu, pemerintah Indonesia membangun usaha dalam sektor publik dan sektor privat. Contoh sektor publik dengan ranah privat antara lain Kantor Perpajakan, Kantor Pelelangan, Pengadilan 
dan lain sebagainya. Sedangkan sektor publik dalam ranah publik yaitu ada BUMN (Badan Usaha Milik Negara).

Badan Usaha Milik Negara (BUMN) merupakan salah satu dari pelaku kegiatan ekonomi yang memegang peranan penting dalam perekonomian nasional, baik sendiri maupun bersama-sama dengan pelaku ekonomi lain yaitu swasta baik dalam skala besar maupun kecil, domestik, juga swasta asing dan koperasi. Sebagai salah satu pelaku kegiatan ekonomi, keberadaan BUMN memiliki peranan besar dalam turut serta mewujudkan kesejahteraan masyarakat.

Badan Usaha Milik Negara merupakan suatu badan hukum yang berbeda dengan badan hukum lainnya. Sesuai dengan yang tercantum dalam Pasal 33 ayat (2) UUD 1945 yang berbunyi: "Cabangcabang produksi yang penting bagi negara dan yang menguasai hajat hidup orang banyak dikuasai oleh negara". Dari pasal tersebut, dapat ditarik kesimpulan bahwa Negara sebagai penguasa atau pemilik dari BUMN tersebut perlu menyertakan modal demi BUMN itu sendiri.

Agar dapat terus produktif, Badan Usaha harus memberikan perhatian khusus dalam penggunaan dananya. Penyediaan dana dapat berasal dari sumber internal yaitu laba ditahan dan eksternal yaitu hutang jangka panjang, hutang jangka pendek, dan modal saham.

Dalam keadaan tertentu badan usaha dapat memenuhi kebutuhan dananya dengan mengutamakan sumber yang berasal dari dalam, namun karena adanya pertumbuhan, maka kebutuhan dana akan semakin besar, sehingga dalam memenuhi kebutuhan tersebut, maka badan usaha harus menggunakan dana yang berasal dari luar perusahaan yaitu liabilitas (hutang).

Hutang adalah kewajiban untuk menyerahkan uang, barang, atau jasa kepada pihak lain dimasa yang akan datang sebagai akibat dari transaksi yang telah terjadi dimasa yang lalu atau sebelumnya. Ditinjau dari jangka waktu pelunasan atau alat pelunasan dapat dibagi menjadi dua, yaitu hutang jangka pendek (hutang lancar) dan hutang jangka panjang.

Akan tetapi dalam penggunaan hutang ini, perlu adanya kehati-hatian atas risiko yang diakibatkan dari hutang tersebut. Karena dana eksternal tersebut dapat menyebabkan badan usaha menghadapi masalah yang berhubungan dengan kemampuaan badan usaha dalam memenuhi kewajibannya, baik kewajiban jangka pendek maupun jangka panjang. Masalah tersebut dikenal dengan kata likuiditas.

Oleh sebab itu dalam mengambil keputusan dalam menggunakan hutang, badan usaha harus memperhatikan perimbangan antara modal sendiri dan modal luar yang akan digunakan. Jika penggunaan dana luar lebih kecil daripada modal sendiri, maka penggunaan modal luar tersebut layak digunakan, namun jika penggunaan modal luar lebih besar dari pada modal sendiri, maka penggunaan modal luar tersebut tidak layak digunakan. (Riyanto, $2001: 23$ )

Selain itu, hutang juga dapat memengaruhi besar kecilnya penghasilan pada suatu badan usaha disetiap akhir periodenya. Karena pada dasarnya setiap badan usaha pasti memiliki penghasilan disetiap akhir periodenya, sekalipun itu merupakan Badan Usaha Milik Negara. Karena penghasilan tersebut dapat digunakan untuk membiayai operasional perusahaan dalam pencapaian penghasilan yang lebih maksimal, melunasi hutang yang ada, sebagai cadangan dana untuk kebutuhan perusahaan, dan untuk perkembangan perusahaan dimasa yang akan datang.

Badan Penyelenggaraan Jaminan Sosial (BPJS) Ketenagakerjaan merupakan Badan Usaha Milik Negara yang memberikan perlindungan bagi tenaga kerja untuk mengatasi risiko sosial ekonomi tertentu dan penyelenggaraannya penggunakan mekanisme asuransi. Disetiap tahunnya badan usaha memiliki kenaik turunan pada liabilitas (hutang) nya. Hal tersebut juga dapat memicu kenaik turunannya Penghasilan Bersih pada setiap periodenya.

\section{Pertanyaan Penelitian}

Berdasarkan uraian latar belakang diatas, maka penulis merumuskan beberapa permasalahan yang menjadi pokok pembahasan dalam penelitian ini. antara lain:

1. Bagaimana Perkembangan Liabilitas pada Badan Penyelenggaraan Jaminan Sosial (BPJS) Ketenagakerjaan Periode 2013-2017?

2. Bagaimana Perkembangan Penghasilan Bersih pada Badan Penyelenggaraan Jaminan Sosial (BPJS) Ketenagakerjaan Periode 2013-2017?

3. Bagaimana Pengaruh Liabilitas terhadap Penghasilan Bersih pada Badan Penyelenggaraan Jaminan Sosial (BPJS) Ketenagakerjaan Periode 2013-2017?

4. Masalah apa saja yang ada kaitannya dengan Liabilitas dan Penghasilan Bersih pada Badan Penyelenggaraan Jaminan Sosial (BPJS) Ketenagakerjaan Periode 2013-2017?

5. Apa upaya yang dapat dilakukan dalam menyelesaikan masalah yang berkaitan dengan Liabilitas dan Penghasilan Bersih pada Badan Penyelenggaraan Jaminan Sosial (BPJS) Ketenagakerjaan Periode 2013-2017? 


\section{Tujuan Penelitian}

Berdasarkan pertanyaan diatas, maka tujuan dari penelitian ini adalah sebagai berikut:

1. Untuk mengetahui Perkembangan Liabilitas pada Badan Penyelenggaraan Jaminan Sosial (BPJS) Ketenagakerjaan Periode 2013-2017.

2. Untuk mengetahui Perkembanga Penghasilan Bersih pada Badan Penyelenggaraan Jaminan Sosial (BPJS) Ketenagakerjaan Periode 2013-2017.

3. Untuk mengetahui Pengaruh Liabilitas terhadap Penghasilan Bersih pada Badan Penyelenggaraan Jaminan Sosial (BPJS) Ketenagakerjaan Periode 2013-2017.

4. Untuk mengetahui masalah apa saja yang ada berkaitan dengan Liabilitas dan Penghasilan Bersih pada Badan Penyelenggaraan Jaminan Sosial (BPJS) Ketenagakerjaan Periode 2013-2017.

5. Untuk mengetahui upaya apa saja yang dapat dilakukan untuk menyelesaikan masalah yang berkaitan dengan Liabilitas dan Penghasilan Bersih pada Badan Penyelenggaraan Jaminan Sosial (BPJS) Ketenagakerjaan periode 2013-2017.

\section{Manfaat Penelitian}

Berdasarkan tujuan penelitian diatas, maka kegunaan penulisan tugas akhir ini adalah sebagai berikut:

\section{Bagi Perusahaan}

Dari hasil penelitian ini diharapkan mampu memberikan masukan sebagian bahan pertimbangan dalam mengatur tingkat liabilitas dan memberikan informasi dalam pengendalian liabilitas.

\section{Bagi Penulis}

Untuk memperoleh wawasan dan pengembangan ilmu yang telah didapat pada saat kuliah, khususnya yang berhubungan dengan judul penelitian. Serta untuk melengkapi dan memenuhi syarat dalam menempuh sidang Program Studi Diploma III Administrasi Keuangan di Politeknik Piksi Ganesha Bandung.

\section{Bagi Pihak Lain}

Sebagai referensi bagi peneliti selanjutnya dalam meyelesaikan tugas akhir dan menambah wawasan mengenai pengaruh Liabilitas terhadap Penghasilan Bersih.

\section{B. KAJIAN ILMIAH}

\section{PENGaRUH}

Menurut Hugiono dan Poerwantana (2000:47) "Pengaruh merupakan dorongan atau bujukan dan bersifat membentuk atau merupakan suatu efek."

Sedangkan menurut Badudu dan Zain (2001:131) Pengaruh adalah daya yang menyebabkan sesuatu terjadi, sesuatu yang dapat membentuk atau mengubah sesuatu yang lain dan tunduk atau mengikuti karena kuasa atau kekuasaan orang lain.

\section{LIABILITAS}

Menurut Munawir (2014:18), Hutang adalah semua kewajiban keuangan perusahaan kepada pihak lain yang belum terpenuhi, dimana hutang ini merupakan sumber dana atau modal perusahaan yang berasal dari kreditor.

Menurut Hery (2011:10) Utang (liabilities) merupakan kewajiban perusahaan kepada kreditur (supplier, bankir) dan pihak lainnya (karyawan, pemerintah). Kreditur dan pihak lainnya disini memiliki hak/klaim atas asset perusahaan.

\section{PENGHASILAN BERSIH}

Haryono Yusup (2013:30), "Penghasilan adalah aliran penerimaan kas atau aset lain yang diterima dari konsumen sebagai hasil penjualan barang atau jasa. Penghasilan meliputi pendapatan dan keuntungan.”

Penghasilan Bersih juga merupakan penghasilan yang didapat setelah dikurangi pajak. Atau dalam arti lain Penghasilan Bersih bisa disebut sebagai Laba Bersih Setelah Pajak.

\section{BEBAN PAJAK}

Menurut Siti resmi (2009:88): "Beban Pajak Penghasilan adalah yang dikenakan terhadap subjek pajak atau penghasilan yang diterima atau diperoleh dalam satu tahun pajak".

Sedangkan menurut Waluyo (2008:215): Beban Pajak adalah jumlah agregat pajak kini dan pajak tangguhan yang diperhitungkan dalam perhitungan laba rugi akuntansi pada suatu atau dalam periode perjalanan sebagai beban atau penghasilan. 


\section{METODE}

\section{Metodologi Penelitian}

Menurut Sugiyono (2016:6) mengemukakan: Metode Penelitian dapat diartikan sebagai cara ilmiah yang berlaku untuk mendapatkan data objektif, valid dan reliable dengan tujuan dapat ditemukan, dibuktikan dan dikembangkan suatu pengetahuan, sehingga dapat digunakan.

Jenis metode penelitian yang digunakan dalam penyusunan Tugas Akhir ini adalah metode penelitian kuantitatif, yaitu penelitian yang dilakukan adalah penelitian yang menekankan pada analisis data numeric (angka). dengan menggunakan metode penelitian ini akan diketahui hubungan yang signifikan antara variabel yang diteliti, sehingga menghasilkan kesimpulan yang akan memperjelas gambar objek yang diteliti.

Menurut Sugiyono (2014:7), "Metode kuantitatif adalah metode yang sering disebut sebagai metode positivistik karena berlandaskan pada filsafat positivisme". Metode ini sebagai metode ilmiah karena telah memenuhi kaidah-kaidah ilmiah yang konkrit/empiris, obyektif, karena dengan metode ini dapat ditemukan dan dikembangkan sebagai iptek baru. Metode ini disebut metode kuantitatif karena data penelitian berupa angka-angka dan analisis menggunakan statistik.

Suatu penelitian bertujuan untuk memberikan gambaran tentang keadaan suatu objek penelitian dan menyampaikan materi laporan yang dilakukan dengan dijabarkan secara rinci dan spesifik yang nampak dan nyata pada situasi yang diselidiki atau dalam keadaan yang sebenarnya dengan melihat fakta-fakta yang ada, dimana data yang diperoleh dapat memberikan gambaran yang jelas terhadap objek yang diteliti.

\section{Definisi Operasional Variabel}

Menurut Sugiyono (2016:61) mengemukakan bahwa: Variabel penelitian adalah suatu atribut atau sifat atau nilai dari orang, obyek, atau kegiatan yang mempunyai variasi tertentu yang diterapkan oleh peneliti untuk dipelajari dan kemudian ditarik kesimpulannya.

Dalam penelitian ini penulis menggunakan data variabel yaitu :

a. Variabel Bebas (Independent Variable)

Variabel Bebas (Independent Variable) yaitu variabel yang menjadi sebab terjadinya pengaruh. Variabel yang digunakan dalam penelitian ini adalah Liabilitas (X).

b. Variabel Terikat (Dependent Variable)

Variabel Terikat (Dependent Variable) yaitu variabel yang nilainya dipengaruhi oleh variabel bebas (Independent Variable) variabel yang digunakan dalam penelitian ini adalah Penghasilan $\operatorname{Bersih}(\mathrm{Y})$.

\section{Populasi dan Sampel Penelitian}

a. Populasi

Menurut Sugyiono (2015:80) mengemukakan: Populasi adalah wilayah generalisasi yang terdiri atas obyek/subyek yang mempunyai kualitas dan karakteristik tertentu yang ditetapkan oleh peneliti untuk dipelajari dan kemudian ditarik kesimpulannya.

Dalam penelitian ini populasi yang digunakan penulis adalah laporan neraca dan laba rugi pada Badan Penyelenggaraan Jaminan Sosial (BPJS) Ketenagakerjaan.

\section{b. Sampel}

Menurut Sugiyono (2015:81) mengemukakan "Sampel adalah bagian dari jumlah dan karakteristik yang dimiliki oleh populasi tersebut".

Dalam penelitian ini sampel yang digunakan adalah total Liabilitas dan Penghasilan Bersih pada Badan Penyelenggaraan Jaminan Sosial (BPJS) Ketenagakerjaan Periode 2013-2017.

c. Sampling

Menurut Sugiyono (2014:116) "Teknik sampling adalah teknik pengambilan sampel, untuk menentukan sampel yang akan digunakan dalam penelitian". Dalam penelitian ini, teknik sampling yang digunakan oleh penulis adalah teknik purposive sampling.

Menurut Sugiyono (2014:122) "Purposive sampling adalah teknik penentuan sampel dengan pertimbangan tertentu". Alasan menggunakan teknik purposive sampling adalah karena tidak semua sampel memiliki kriteria yang sesuai. Kriteria yang dijadikan sampel penelitian adalah Total Liabilitas dan Penghasilan Bersih Periode 2013-2017 karena pada periode tersebut adanya pengaruh eksternal maupun internal yang mempengaruhi. 


\section{Sumber dan Teknik Pengumpulan Data}

a. Studi Pustaka (Library Research)

Yaitu pengumpulan data dan mempelajari atau membaca pendapat para ahli yang berhubungan dengan permasalahan yang akan diteliti untuk memperoleh landasan teori-teori yang dapat menunjang penelitian yang dibuat mempunyai landasan teoritis yang kuat dan menunjang.

b. Studi Lapangan (Fild Research)

Dalam penelitian ini melakukan pengumpulan data dengan cara terjun langsung ke lapangan untuk mengumpulkan, mengolah dan menganalisis data yang diperlukan, sedangkan data yang ditempuh dalam penelitian ini di lapangan adalah sebagai berikut :

a) Observasi

Observasi merupakan suatu kegiatan yang dilakukan oleh peneliti dengan cara terjun langsung ke lapangan untuk memperoleh data yang dapat digunakan untuk penelitian, dalam penelitian ini penulis melakukan participant observation yaitu peneliti secara langsung terlibat dalam kegiatan sehari-hari perusahaan yang diamati sebagai sumber data.

\section{b) Dokumentasi}

Dokumentasi merupakan catatan peristiwa yang telah berlalu. Dokumentasi bisa berbentuk tulisan, gambar atau karya-karya.

c) Browsing Internet

Browsing internet adalah cara memperoleh data dengan mengunjungi situs-situs internet yang terkait dengan permasalah yang diteliti.

\section{HASIL DAN PEMBAHASAN}

1. Perkembangan Liabilitas BPJS Ketenagakerjaan periode 2013-2017

Tabel 3.1

Data liabilitas pada Badan Penyelenggaraan Jaminan Sosial (BPJS)

Ketenagakerjaan periode 2013-2017

\begin{tabular}{|c|c|c|c|}
\hline TUHAN & LIABILITAS & PERSENTASE & KET. \\
\hline 2013 & Rp13.095.457.624.283 & - & - \\
\hline 2014 & Rp2.300.922.095.015 & $82,43 \%$ & Turun \\
\hline 2015 & Rp2.154.835.704.853 & $6,35 \%$ & Turun \\
\hline 2016 & Rp2.945.230.617.618 & $36,68 \%$ & Naik \\
\hline 2017 & Rp2.534.574.941.132 & $13,94 \%$ & Turun \\
\hline JUMLAH & Rp23.031.020.982.901 & & \\
\hline $\begin{array}{l}\text { RATA- } \\
\text { RATA }\end{array}$ & Rp4.606.204.196.580 & & \\
\hline
\end{tabular}

Sumber: Diolah oleh Penulis (2019)

Gambar 3.3 Diagram Batang

Liabilitas pada Badan Penyelenggaraan Jaminan Sosial (BPJS)

Ketenagakerjaan periode 2013-2017 


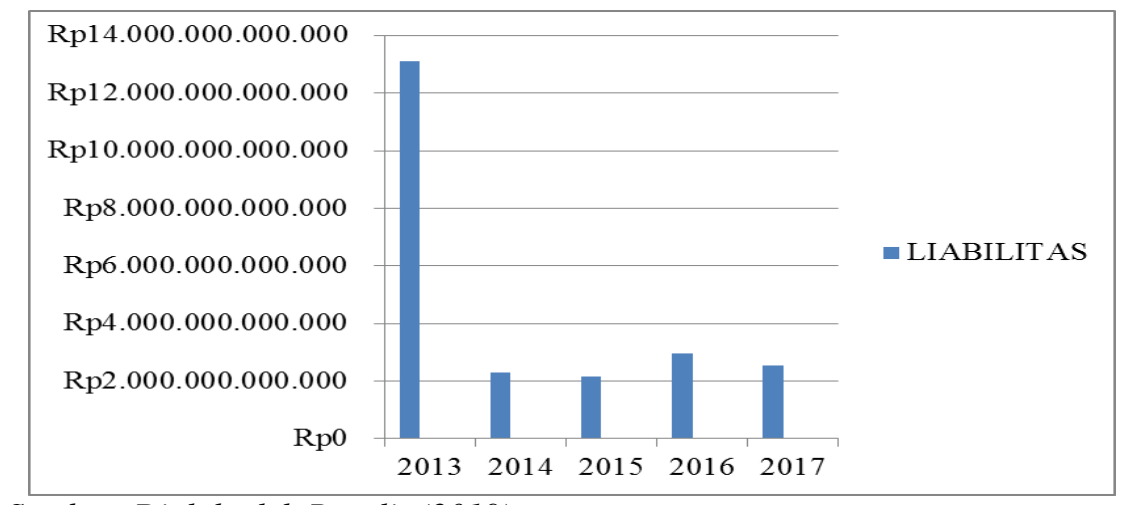

Sumber: Diolah oleh Penulis (2019)

Berdasarkan tabel diatas dapat dilihat bahwa liabilitas pada Badan Penyelenggara Jaminan Sosial (BPJS) Ketenagakerjaan mengalami nilai yang sangat besar pada tahun 2013 dibandingkan tahuntahun berikutnya, hal tersebut dikarenakan pada tahun 2013 terdapat cadangan teknis yang cukup besar. Sedangkan pada tahun 2014-2015 selalu terjadi penurunan, hal tersebut diakibatkan karena adanya penurunan saldo Utang Pajak dan Liabilitas Jangka Pendek. Tetapi pada tahun 2016 liabilitas perusahaan mengalami peningkatan dibandingkan dengan tahun sebelumnya, hal tersebut diakibatkan karena adanya peningkatan atas utang pajak, beban akrual dan liabilitas imbalan kerja jangka panjang. Dan pada tahun 2017 terlihat adanya penurunan liabilitas kembali, hal tersebut terjadi karena adanya pelunasan kewajiban kepada pihak ketiga dan menurunnya beban akrual seperti beban usaha yang masih harus dibayar, selain itu menurunnya nilai utang pajak tahun 2017 juga mengakibatkan nilai liabilitas menjadi turun dari perusahaan.

\section{Perkembangan Penghasilan Bersih pada BPJS Ketenagakerjaan Periode 2013-2017}

Tabel 3.2

Penghasilan Bersih pada Badan Penyelenggaraan Jaminan Sosial (BPJS) Ketenagakerjaan periode 2013-2017.

\begin{tabular}{|c|c|c|c|}
\hline TAHUN & PENGHASILAN BERSIH & $\begin{array}{c}\text { PERSENT } \\
\text { ASE }\end{array}$ & KET \\
\hline 2013 & Rp2.287.643.097.173 & - & - \\
\hline 2014 & Rp712.931.219.955 & $68,84 \%$ & Turun \\
\hline 2015 & Rp622.469.366.337 & $12,69 \%$ & Turun \\
\hline 2016 & Rp1.072.534.600.809 & $72,30 \%$ & Naik \\
\hline 2017 & Rp1.299.523.515.598 & $21,16 \%$ & Naik \\
\hline JUMLAH & Rp5.995.101.799.872 & & \\
\hline $\begin{array}{l}\text { RATA- } \\
\text { RATA }\end{array}$ & Rp1.199.020.359.974 & & \\
\hline
\end{tabular}




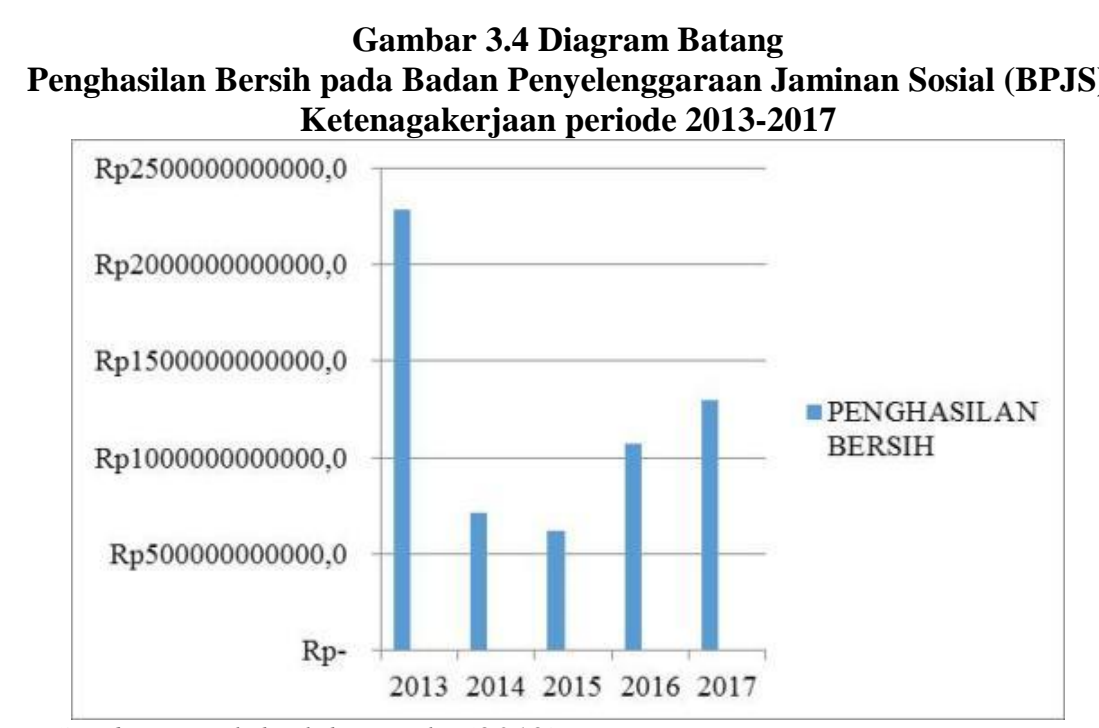

Sumber: Diolah oleh Penulis (2019)

Berdasarkan tabel diatas dapat dilihat bahwa Penghasilan Bersih pada Badan Penyelenggaraan Jaminan Sosial (BPJS) Ketenagakerjaan tahun 2013 memiliki nilai yang cukup tinggi dibandingkan tahun-tahun berikutnya, hal tersebut diakibatkan karena adanya penerimaan iuran dan hasil investasi yang cukup tinggi. Sedangkan pada tahun 2014-2015 mengalami penurunan yang diakibatkan karena adanya beban investasi yang harus dibayarkan. Namun pada tahun 2016-2017 Penghasilan Bersih selalu mengalami kenaikan, hal tersebut didapat karena adanya penerimaan dari entitas anak.

3. Pengaruh Liabilitas terhadap Penghasilan Bersih pada BPJS Ketenagakerjaan Periode 20132017

Berdasarkan data yang diperoleh, selanjutnya akan dilakukan analisa dan perhitungan tentang bagaimana pengaruh Liabilitas terhadap Penghasilan Bersih pada BPJS Ketenagakerjaan Periode 2013-2017. Dalam penelitian ini data diolah menggunakan SPSS versi 20. Adapun hasil perhitungan tersebut adalah sebagai berikut:

1. Uji Normalitas Data

Tujuan dilakukan uji normalitas data adalah untuk mengetahui apakah suatu variabel normal atau tidak. Kriteria pengujian normalitas menurut Sugiyono (2016:241) adalah "Jika signifikasi kurang dari 0,05 maka kesimpulannya tidak berdistribusi normal, tetapi jika signifikasinya lebih dari 0,05 maka berdistribusi normal"

Berikut ini adalah hasil uji normalitas menggunakan SPSS versi 20:

Tabel 3.4

Hasil Perhitungan Uji Normalitas Data

\begin{tabular}{|c|c|c|c|}
\hline \multicolumn{4}{|c|}{ One-Sample Kolmogorov-Smirnov Test } \\
\hline & Liabilitas & $\begin{array}{l}\text { Penghasil } \\
\text { an Bersih }\end{array}$ \\
\hline \multicolumn{2}{|l|}{ N } & 5 & 5 \\
\hline \multirow{2}{*}{$\begin{array}{l}\text { Normal } \\
\text { Parameters } \\
\text { a,b }\end{array}$} & Mean & $4,6062 \mathrm{E}+12$ & $1,199 \mathrm{E}+12$ \\
\hline & Std. Deviation & $4,75504 \mathrm{E}+12$ & $6,671 \mathrm{E}+11$ \\
\hline \multirow{3}{*}{$\begin{array}{l}\text { Most } \\
\text { Extreme } \\
\text { Difference } \\
\mathrm{s}\end{array}$} & Absolute & 0,437 & 0,24 \\
\hline & Positive & 0,437 & 0,24 \\
\hline & Negative & $-0,303$ & $-0,194$ \\
\hline \multicolumn{2}{|c|}{ Kolmogorov-Smirnov Z } & 0,976 & 0,537 \\
\hline \multicolumn{2}{|c|}{ Asymp. Sig. (2-tailed) } & 0,296 & 0,935 \\
\hline \multicolumn{4}{|c|}{ a. Test distribution is Normal. } \\
\hline \multicolumn{4}{|c|}{ b. Calculated from data. } \\
\hline
\end{tabular}

Sumber: Diolah oleh Penulis menggunakan SPSS versi 20 (2019) 
Berdasarkan data diatas, diketahui bahwa nilai signifikan (asymp.sig) signifikan adalah sebesar 0,296 dan 0,935 yang artinya lebih besar dari 0,05 dan apabila probabilitas > dari 0,05 maka Ho dapat diterima. Sehingga dapat disimpulkan bahwa Pengaruh Liabilitas terhadap Penghasilan Bersih pada Badan Penyelenggaraan Jaminan Sosial (BPJS) Ketenagakerjaan berdistribusi Normal.

\section{Analisis Regresi Linear Sederhana}

Manfaat dari hasil analisis regresi adalah untuk membuat keputusan apakah nilai naik dan menurunnya variabel terikat (Penghasilan Bersih) dapat dilakukan melalui peningkatan variabel bebas (Liabilitas) atau tidak.

Dalam penelitian ini yang menjadi variabel independent $(\mathrm{X})$ adalah Liabilitas, sedangkan untuk variabel dependent (Y) adalah Penghasilan Bersih. Berikut merupakan hasil pengujian analisis regresi linier sederhana menggunakan SPSS versi 20.

Tabel 3.5

Hasil Analisis Regresi Linear Sederhana Liabilitas dengan Penghasilan Bersih

Coefficients $^{\text {a }}$

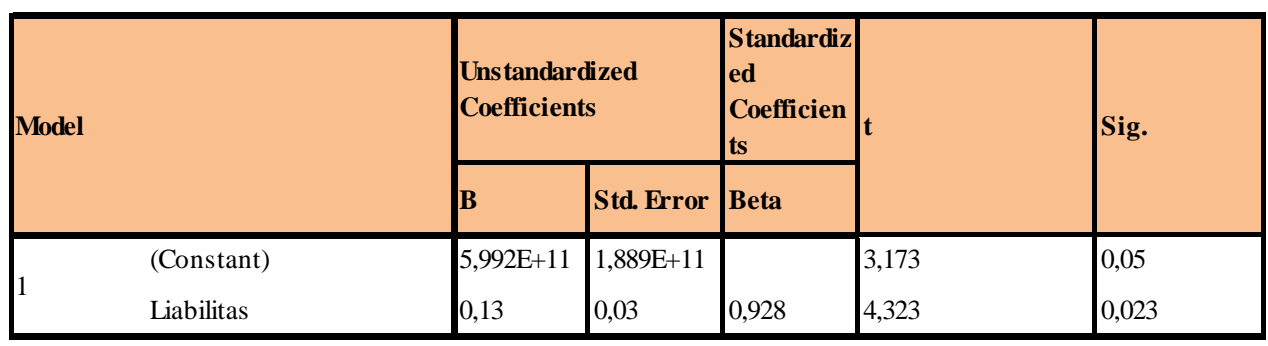

a. Dependent Variable: Penghasilan Bersih

Sumber: Diolah oleh Penulis menggunakan SPSS versi 20 (2019)

Persamaan umum regresi linier sederhana adalah :

$$
\mathbf{Y}=\mathbf{a}+\mathbf{b X}
$$

Setelah a dan $b$ ditemukan, maka persamaan regresi linier sederhana dapat disusun sehingga persamaan nilai penjualan dan aktiva lancar adalah seperti berikut :

$$
Y=599195049263,286+0,130 X
$$

Berdasarkan data di atas, diketahui nilai a sebesar 599195049263,286 yang artinya jika liabilitas (X) sama dengan nol maka nilai Penghasilan Bersih (Y) adalah sebesar 599195049263,286. Dan untuk nilai $b$ diketahui sebesar 0,130 yang artinya setiap penambahan Rp 1.000,- tingkat liabilitas (X) maka Penghasilan Bersih (Y) akan meningkat sebesar Rp 130,-. Karena koefisien regresi bernilai positif (+), maka dengan demikian dapat disimpulkan bahwa liabilitas berpengaruh positif terhadap Penghasilan Bersih.

3. Analisis Koefisien Korelasi Pearson (Pearson Product Moment)

Analisis koefisien korelasi adalah sekumpulan teknik yang digunakan untuk mengukur keeratan hubungan (korelasi) antara suatu variabel dengan variabel yang lainnya. Dua variabel dikatakan korelasi apabila perubahan salah satu variabel disertai dengan perubahan lainnya, baik dalam arah yang sama ataupun arah yang sebaliknya. Nilai koefisien korelasi yang kecil bukan berarti kedua variabel tidak saling berhubungan.

Tabel 3.7

Hasil Analisis Koefisien Korelasi Pearson (Pearson Product Moment) 


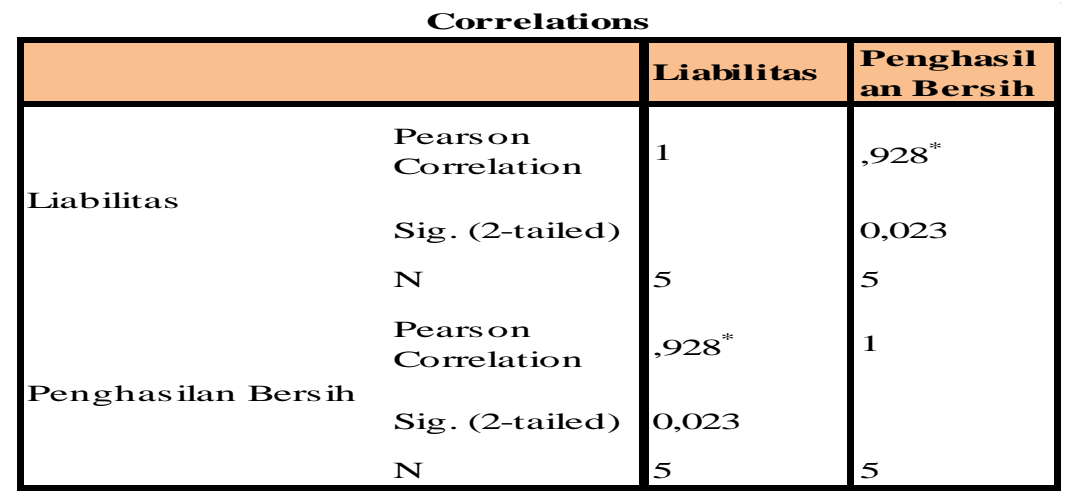

*. Correlation is significant at the 0.05 level (2-tailed).

Sumber: Data diolah Penulis menggunakan SPSS versi 20 (2019)

Berikut adalah hasil perhitungan Koefisien Korelasi Pearson (Pearson Product Moment) jika dihitung menggunakan rumus:

$$
\begin{aligned}
r & =\frac{n \sum X Y-\left(\sum X\right)\left(\sum Y\right)}{\sqrt{\left(n \sum(X)^{2}-\left(\sum X\right)^{2}\left(n \sum(Y)^{2}-\left(\sum Y\right)^{2}\right)\right.}} \\
& =\frac{58.888 .019}{63.44084023} \\
& =0,928235168
\end{aligned}
$$

Dari data diatas diketahui hasil pengujian analisis pearson sebesar 0,928 yang artinya bahwa kedua variabel memiliki hubugan linier positif yang sangat kuat.

Selain itu, hubungan kedua variabel adalah signifikan. Hal tersebut dilihat dari angka signifikansi (Sig. 2-tailed) sebesar 0,023 yang artinya lebih kecil dari 0,05 sehingga jika angka signifikansi hasil penelitian kurang dari 0,05 maka hubungan antara kedua variabel adalah signifikan.

\section{Koefisien Determinasi}

Koefisien determinasi merupakan suatu ukuran penting dalam regresi, karena dapat menginformasikan baik atau tidaknya model regresi yang terestimasi atau dengan kata lain angka tersebut dapat mengukur seberapa besar dekatnya garis regresi terestimasi dengan data

yang sesungguhnya. Untuk mengetahui seberapa besar pengaruh variabel $\mathrm{X}$ (Liabilitas) terhadap variabel Y (Penghasilan Bersih), maka perlu dihitung menggunakan bantuan program komputer yaitu SPSS versi 20 sebagai berikut :

\begin{tabular}{|c|c|c|c|c|}
\hline \multicolumn{5}{|c|}{ Model Summary ${ }^{b}$} \\
\hline Model & $\mathrm{R}$ & R Square & Aajustea & Sta. Error \\
\hline 1 & $.928^{\mathrm{a}}$ & 0,862 & 0,816 & $2,865 \mathrm{E}+11$ \\
\hline
\end{tabular}

Tabel 3.8

Hasil Perhitungan Koefisien Determinasi

a. Predictors: (Constant), Liabilitas

b. Dependent Variable: Penghasilan Bersih

Sumber: Data diolah penulis menggunakan SPSS versi 20 (2019)

Berikut adalah hasil perhitungan Koefisien Determinasi jika dihitung secara manual menggunakan rumus:

$$
\begin{aligned}
& \text { KD }=r^{2} \times \mathbf{1 0 0 \%} \\
& =(0,928)^{2} \times 100 \% \\
& =86,12 \%
\end{aligned}
$$

Berdasarkan data pada tabel diatas dapat disimpulkan bahwa pengaruh Liabilitas terhadap Penghasilan Bersih adalah sebesar 0,862 atau sama dengan 86,20\% yang ditunjukan oleh $\mathrm{R}$ Square, sedangkan sisanya $13,80 \%$ dipengaruhi oleh faktor lainnya yang tidak diteliti oleh penulis.

\section{Pengujian Hipotesis Uji-t}

Uji-T digunakan untuk menguji secara parsial masing-masing variabel. Uji-T dimulai dengan penetapan hipotesis nol dan hipotesis alternatif, penelitian uji statistik dan perhitungan uji statistik, 
perhitungan hipotesis, penetapan tingkat signifikan dan penarikan kesimpulan. Hipotesis yang akan digunakan dalam penelitian ini berkaitan dengan ada atau tidaknya pengaruh variabel (X) terhadap variabel (Y) serta seberapa besar pengaruhnya.

Tabel 3.9

Hasil Pengujian Hipotesis dengan Uji-T

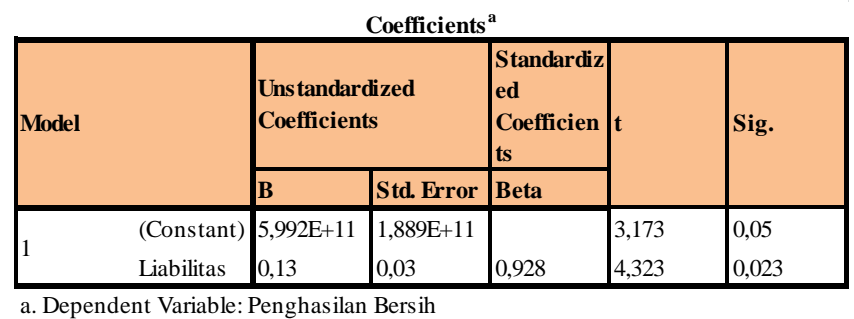

Sumber: Data diolah Penulis menggunakan SPSS versi 20 (2019)

Berikut adalah hasil pengujian Hipotesis dengan Uji-T jika dihitung secara manual menggunakan rumus:

$$
\begin{gathered}
t=\frac{r \sqrt{n-2}}{\sqrt{1-r^{2}}} \\
=\frac{1,607750472}{0,371993914} \\
=4,32198058
\end{gathered}
$$

Berdasarkan data di atas diketahui bahwa nilai t hitung adalah sebesar 4,323 sedangkan t tabel sebesar 3,182 dengan signifikasi $0,023<0,05$. Ternyata hasil $\mathrm{t}$ hitung lebih besar dari $\mathrm{t}$ tabel $(4,323>3,182)$ yang artinya Ho ditolak dan Ha diterima. Sehingga dapat ditarik kesimpulan bahwa Liabilitas berpengaruh positif dan signifikan terhadap Penghasilan Bersih pada Badan Penyelenggaraan Jaminan Sosial (BPJS) Ketenagakerjaan.

\section{E. PENUTUP}

\section{Kesimpulan}

Berdasarkan penelitian yang telah dilakukan pada Badan Penyelenggaraan Jaminan Sosial (BPJS) Ketenagakerjaan, maka dpaat disimpulkan sebagai berikut:

a. Berdasarkan tabel diatas dapat dilihat bahwa liabilitas pada Badan Penyelenggara Jaminan Sosial (BPJS) Ketenagakerjaan mengalami nilai yang sangat besar pada tahun 2013 dibandingkan tahun-tahun berikutnya, hal tersebut dikarenakan pada tahun 2013 terdapat cadangan teknis yang cukup besar. Sedangkan pada tahun 2014-2015 selalu terjadi penurunan, hal tersebut diakibatkan karena adanya penurunan saldo Utang Pajak dan Liabilitas Jangka Pendek. Tetapi pada tahun 2016 liabilitas perusahaan mengalami peningkatan dibandingkan dengan tahun sebelumnya, hal tersebut diakibatkan karena adanya peningkatan atas utang pajak, beban akrual dan liabilitas imbalan kerja jangka panjang. Dan pada tahun 2017 terlihat adanya penurunan liabilitas kembali, hal tersebut terjadi karena adanya pelunasan kewajiban kepada pihak ketiga dan menurunnya beban akrual seperti beban usaha yang masih harus dibayar, selain itu menurunnya nilai utang pajak tahun 2017 juga mengakibatkan nilai liabilitas menjadi turun dari perusahaan.

b. Berdasarkan tabel diatas dapat dilihat bahwa Penghasilan Bersih pada Badan Penyelenggaraan Jaminan Sosial (BPJS) Ketenagakerjaan tahun 2013 memiliki nilai yang cukup tinggi dibandingkan tahun-tahun berikutnya, hal tersebut diakibatkan karena adanya penerimaan iuran dan hasil investasi yang cukup tinggi. Sedangkan pada tahun 2014-2015 mengalami penurunan yang diakibatkan karena adanya beban investasi yang harus dibayarkan. Namun pada tahun 2016-2017 Penghasilan Bersih selalu mengalami kenaikan, hal tersebut didapat karena adanya penerimaan dari entitas anak.

c. Pengaruh Liabilitas Terhadap Penghasilan Bersih pada Badan Penyelenggaraan Jamina Sosial (BPJS) Ketenagakerjaan yaitu sebesar 86,20\% dan sisanya 13,80\% dipengaruhi oleh faktor lain dengan hubungan antar kedua variabel tersebut sangat erat, yaitu sebesar 0,928. 
Selain itu, Hasil uji Hipotesis t hitung adalah t hitung lebih besar dari t tabel $(4,323>3,182)$ yang artinya Ho ditolak dan Ha diterima. Sehingga dapat ditarik kesimpulan bahwa Liabilitas berpengaruh positif terhadap Penghasilan Bersih.

d. Hambatan yang dihadapi Badan Penyelenggaraan Jaminan Sosial (BPJS) Ketenagakerjaan yaitu besarnya Utang Pajak yang diterima, hal tersebut diakibatkan karena besarnya penerimaan penghasilan bersih. Adapun kenaikan pada Beban Akrual dan Liabilitas imbalan jangka panjang yang mengakibatkan meningkatnya nilai Liabilitas.

e. Upaya yang dilakukan untuk menyelesaikan masalah yang berkaitan dengan Liabilitas terhadap Penghasilan Bersih pada Badan Penyelenggaraan Jaminan Sosial (BPJS) Ketenagakerjaan yaitu dengan mulai rutinnya pembayaran utang pajak dan adanya penurunan 2. Saran atas Beban Akrual yang dapat memicu terhadap bertambahnya nilai Penghasilan Bersih.

Adapun saran yang penulis berikan sebagai bahan pertimbangan bagi Badan Penyelenggaraan Jaminan Sosial (BPJS) Ketenagakerjaan, khususnya mengenai pengaruh liabilitas terhadap Penghasilan Bersih adalah sebagai berikut:

1. Badan Penyelenggaraan Jaminan Sosial (BPJS) Ketenagakerjaan sebaiknya lebih memperhatikan beban-beban yang dapat memicu kenaikan liabilitas seperti beban akrual dan liabilitas imbalan jangka panjang. Sehingga dapat meminimalisir aktivitas beban-beban tersebut.

2. Badan Penyelenggaraan Jaminan Sosial (BPJS) Ketenagakerjaan sebaiknya mengadakan kembali pemulihan nilai wajar aset investasi yang tersedia dijual, agar terus dapat meningkatkan penghasilan operasionalnya.

\section{F. DAFTAR PUSTAKA}

Badudu, J.S dan Zain (2001), Kamus Umum Bahasa Indonesia, Pustaka Sinar Harapan : Jakarta.

Hery (2011), Akuntansi Perusahaan Jasa dan Dagang, Alfabeta : Bandung.

Hugiono dan Poerwantana (2000), Pengantar Ilmu Sejarah, PT Bina Aksara : Jakarta.

Kasmir (2014), Analisis Laporan Keuangan, PT Raja Grafindo Persada : Jakarta.

Kasmir (2015), Analisis Laporan Keuangan, Rajawali Pers : Jakarta.

Munawir (2014), Analisa Laporan Keuangan, Liberty Yogyakarta : Yogyakarta.

Nurwahyudi dan Madiyah (2004), Teori dan Analisis Kebijakan Hutang di Indonesia, Mediasoft Indonesia : Jakarta.

Samryn, L.M (2012), Pengantar Akuntansi : Mudah Membuat Jurnal Transaksi Dengan

Pendekatan Siklus Transaksi, Rajawali Pers : Jakarta.

Subramanyam, K.R dan John J. Wild (2014), Analisis Laporan Keuangan, Salemba Empat : Jakarta.

Sugiyono (2012), Metodologi Penelitian Kuantitatif, Kualitatif, R\&D, Alfabeta : Bandung.

Sugiyono (2013), Metodologi Penelitian Kuantitatif,Kualitatif, R\&D, Alfabeta : Bandung.

Sugiyono (2014), Metodologi Penelitian Kuantitatif,Kualitatif, R\&D, Alfabeta : Bandung.

Sugiyono (2015), Metodologi Penelitian Kuantitatif,Kualitatif, R\&D, Alfabeta : Bandung.

Sugiyono (2016), Metodologi Penelitian Kuantitatif,Kualitatif, R\&D, Alfabeta : Bandung. 